\title{
SOME ASPECTS OF THE CULTURAL AND SPIRITUAL LIFE OF JEWS IN ODESSA AS PREREQUISITE OF THE NATIONAL THEATRE
}

\section{Ovcharenko T. S.}

\section{INTRODUCTION}

In the history of Ukraine, the ethnic group of Jews is one of the oldest and most numerous, whose size and forms of settlement have varied constantly over different historical periods. However, there is very little scientific research on the cultural phenomenon of this nation, known worldwide, in Ukrainian and Russian science. This may be due to the lack of a "concise formulation of the basic concepts (a kind of axioms) of a given culture and special linguistic means capable of making the basic concepts of culture equally accessible to each person, regardless of his or her individual perception or social status. ${ }^{1}$ " Probably the reason is the absence of a concept of theoretical research on the problems of Jewish culture "through the lens of modern naiology, which, in turn, should become a methodological basis" ${ }^{2}$.

No scientific studies have been found on the nature and temperament of Jews in Russian and Ukrainian sources. In the article "National image as an element of theatrical culture" the author pays attention to this issue $^{3}$. The national character is connected with traditional forms of people's reactions to relevant life situations. On this basis, some scholars (V. Sukharev, M. Sukharev) understand the national character as somewhat acquired in the process of contacting other people. The national character is different from the national style, which is understood by the behaviors typical of the inhabitants of a country.

\footnotetext{
${ }^{1}$ Найдорф М. И. Введение в теорию культуры: Основные понятия культурологи. Одесса: Друк, 2005. 192 с.

2 Курас I. Ф. Євреї в незалежній Україні: проблеми наукових досліджень. «Політика і час». № 8. 1994. 41-51 с.

${ }^{3}$ Овчаренко Т. С. Національний імідж як елемент театральної культури. Аркадія: культурологічний та мистецтвознавчий журнал. Одеса, 2004. № 2(4). 48-50 c.
} 
This is facilitated by the value system and the country of residence. The term "national character" is not analytical but descriptive, which expresses the specific lifestyle of a particular people. The national character implies a characteristic not of an individual, but of a whole group that has a common culture, traditions, symbols ${ }^{4}$.

The existence of a national character is mentioned in the writings of Herodotus, Y. Caesar, Xenophon. Initially, the national character was associated with the environment and climate in which the people live. Only in the writings of J. Locke, D. Rousseau, G. Hegel, and I. Herder formed a scientific approach to understanding this problem. In $1860 \mathrm{M}$. Latsarus and H. Steintal created a special discipline - psychology of peoples, and in the early twentieth century. ideas of ethnic psychology are supported by W. Wundt in the work "Psychology of Nations" (1900-1920). Ukrainian scientists A. Hnatyuk, M. Drahomanov, M. Hrushevsky, D. Ovsyannik-Kulikovsky played a significant role in the development of the science of the "folk spirit".

The contemporary theoretical studies of the Jewish ethnic group are almost exclusively related almost exclusively to history: E. Greenberg, P. Johnson, S. Dubnov, F. Kandel, I. Kotler, M. Leskov, M. Panchuk, M. Polishchuk, I. Honigsman, S. Zipperstein. In describing the cultural heritage, historians do not analyze the genesis of a particular cultural phenomenon of the Jewish nation. Meanwhile, the emergence of prominent representatives of Jewish ancestry in various forms of art, "... in our and previous generations, had a long and important prehistory that dates back to the ages of about two millennia, and possibly more," says American scientist S. Roth ${ }^{5}$.

Numerous facts of theatrical skills left by Jewish artists in the culture of different peoples lead us to believe that the theater originated in Jews much earlier than the ancient Greek theater, and in such a rapid development such subjective factors as features of national character played a major role, temperament, mentality. The same opinion is shared by such scholars of Jewish theater as M. Beregovsky, E. Binevich, V. Karp, O. Karp, R. Menovich, A. Sidelnikov, and others. And the famous theatrical figure M. Jewish, considered the ancient Greek "song of tsap" borrowed from the religious rite of the Jews of Yom Kippur

${ }^{4}$ Сухарев В. А., Сухарев М. В. Психология народов и наций. Донецк: Сталкер, $1997.400 \mathrm{c}$.

5 Рот С. Искусство в еврейской традици. Иерусалим: Б-ка Алия, 1989. № $852.208 \mathrm{c}$. 
(Day of Atonement), when the high priest by lot one "sacrifices" sacrifice to God, and sends another one to the sacrifice ${ }^{6}$.

Modern scientists of all countries, considering the culture of an individual nation or nation, are increasingly paying attention to the study of subjective factors of culture to which they refer social norms, customs, moral attitudes, values, as well as temperament and national character (E. Aronson, V. Bokan, D. Matsumoto, A. Shvetsova).

With Ukraine's independence, research interest in the Jewish topic has grown significantly. More or less systematic studies of Jewish history appear: S. Zippershtein, "The Jews of Odessa. History of Culture of 1794-1881”, M. Polishchuk“ Jews of Odessa and Novorossiya”, I. Kotler "Essays on the History of the Jews of Odessa", J. Angel and A. Weiss" Genocide against Jews in the Second World War"; T. Grill "The Role of German Jews in Eastern Europe, 1780-1930"; A. Hoffmeister "The Name of Odessa, 1871-1921: Secularization, Nationalization and the Social Issue of Jews in the Russian City", V. Solod "Odessa Museum of Jewish Culture"; T. Steinhoff "Jewish Culture and Literature in Yiddish in Odessa in the XI - XX centuries", V. Proskuryakov "Culturology of the Jewish Theater of Ukraine. In the Context of Time, Action and Architecture", T. Stepanchikova" History of the Jewish Theater in Lviv. Through the thorns-to the stars!”.

\section{The cultural and spiritual life of the Jews in Ukraine and Odessa, in particular}

The earliest evidence of the settlement of Jews in the territory of modern Ukraine dates back to the 1st century. N. Jews settled in the Crimea and on the northern Black Sea coast long before Christianity spread there. This is evidenced by ancient Greek inscriptions found in Kerch, Anapa, Olbia, that "Jews were Hellenists, had Greek names, used Greek, lived in entire communities, went to synagogues, kept slaves and

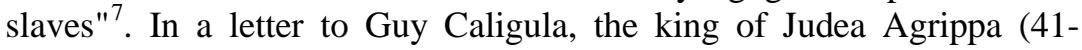
44 AD) informed him about Jewish settlements in the Greek Black Sea colonies. The Jews also left numerous inscriptions in ancient Hebrew ${ }^{8}$.

6 Евреинов Н. Н. Азазел и Дионис. О происхождении сцены в связи с зачатками драмы у семитов. Л.: "ACADEMIA", 1924. 203 с.

7 Малышевский И. Евреи в Южной Руси и Киеве в X-XII веках. Киев, 1878. $116 \mathrm{c}$.

8 Маринович М.Ф. «Про міжконфесійну ситуацію в Україні». Релігійне життя. Права людини в Україні:К.-Х., 1993.с. 50-56. 
Until the VIII century. not. a large number of Jews lived within the Khazar Khaganate, where Judaism was a state religion. The earliest memories of Jewish communities in the city of Kyiv are still relevant. IX - XIII centuries. Mention is made of Jewish merchants from Western and Central Europe who were traveling to Russia (Golkhei Rusya) ${ }^{9}$. A widely known chronicle of the Khazar ambassadors' proposal to Prince Vladimir to accept Judaism. Although the proposal was rejected, the presence of Judaism connoisseurs at the prince's court, their status equal to that of Christian ambassadors from Byzantium and Rome, testifies to a rather tolerant relationship between Russians and Jews. Relatively tolerant was the theological controversy with the supporters of Judaism of Kiev Metropolitan Hilarion (XI century.). There was also a synagogue in which the Jews hid during the riot of 1113 and held siege until the arrival of Vladimir Monomakh. Some historians say that in those days Jews did not differ in language or clothing from the population of Kievan Rus. The differences emerged only after the powerful migration of Jews from Western Europe. In 1356 the first Jewish community in Lviv; in 1404 (Drohobych); in 1410 (Lutsk) $^{10}$. On the territory of the Hajibey fortress, Jews settled in the mid-eighteenth century, as evidenced by historical sources, including an ancient inscription on a Jewish crypt dating from 1770. However, during the Russo-Turkish campaign many of them left the fortress, and when the Russian soldiers stormed it in 1792, six Jews remained in the territory of Hajibey. ${ }^{11}$ During the reign of the Russian Empress Catherine II, who decided to settle Novorossiysk lands conquered by the Turks as soon as possible, granting significant tax exemptions to the migrants, a large number of Jews from the former Polish lands began to move to the south of Ukraine, which gradually acquired the status of a "border" status. Two hundred and forty-six Jews ( $10 \%$ of the total population) lived here with the development of the city of Odessa, the Jewish community was created, the first synagogue was opened (on Balkivska St.), and a Jewish cemetery was founded (1793). Changes in the life of the Jewish community are also taking place with

${ }^{9}$ Історія релігії в Україні: навч. посібник / НАН України. І-нт філософії, Відділ релігієзнавства; За ред.. А.М. Колодного, П.Л. Яроцького. К.: Знання, 1999. 735 c.

${ }^{10}$ Фентон Джон. Древнейшая жизнь евреев. Социологический етюд (перевод с англ.). М.: Типография А. И. Мамонтова и Комп., 1884. № 5.354 с.

${ }^{11}$ Котлер И. Очерки по истории евреев Одессы. Редактор И. Котлер. Иерусалим, 1996. 204 с. 
the development of the city: a new synagogue is being built (on Jewish Street), the first school for children from needy families (Talmud-Torah) is being opened, and a six-bed almshouse that will form the basis of a future Jewish hospital for now.It should be noted that all of these establishments were maintained at the expense of the Jewish community.

From the first years of the city's existence, Jews participated in public life. At that time, when Jews were forbidden to enter the city authorities in other large cities of the Russian Empire, representatives of the Jewish people M. Elmanovich and R. Lazarevich worked in the Odessa magistrate.

Considering that the builders of the city of Odessa were mostly French (where Volan, where Richelieu, where Ribas), who were wellknown for cultural entertainment, entertaining establishments have appeared in the city since the first years of its existence. Stage venues are founded in almost every cafe or restaurant, in the City Garden and on their own villas. Mass celebrations and lottery allegories are held here; carnivals and masquerades; variety theaters include popular vaudeville, one-act comedies, and benefit shows; visitors are invited to a buffet theater, an art café, and gypsy songs are sung at restaurant venues. P. Sumarokov, who visited Odessa at the end of the eighteenth century., In the book "Leisure of the Crimean Judge", positively assessing the plans of the city authorities of Odessa, identified the fact that the authorities want to "build a theater" ${ }^{12}$. Already in 1804, the Austrian, Neapolitan, and Italian consulates were established in Odessa, which provided a place for performances by theater troupes touring in Odessa. Odessans spoke different languages, professed different religions, adhered to different traditions, but always loved various shows, including theatrical performances.

The first national theater in Odessa was the Polish, which in 1805 opened the era of Odessa theaters. The tour of the Polish troupe from Zhytomyr took place in a basement on Rishelevskaya Street, where the military barracks used to be located. An unknown author who wrote the newsletters, and who is believed to have been an actor of the troupe in the past, mentioned in 1822 in the first Odessa Messager newspaper: "... the auditorium was wonderful; it was built in an old barracks, however, the roof was a mess: in bad weather, spectators had to come with umbrellas, but in the hot weather it was very nice. The stage

12 Голота В. В. Театральная Одесса. К.: Мыстэцтво, 1990. 245 с. 
scaffold consisted of a dozen beams of various sizes, skillfully laid on four large tubes. Let's say two words about our scenery. It was the summit of luxury: the back wall of the hall, though, belonged to the barracks, but due to the natural humidity of the building, the wall so blurred that there were large green spots that looked like a lovely garden in the evening.

The backdrops were made of four old stairs, which were glued together with beautiful wallpapers of blue on one side (it was the sky), and dark green on the other (it was a grove). The hall was illuminated by four oil candles. On the stage of the theater played everything: drama, melodrama, farce, comedy, ballet ${ }^{13}$. An example of this room is to understand the conditions in which theater actors worked. In 1809, the first City Theater was opened in Odessa under the design of St. Petersburg architect Tom de Thomson.The theater accommodated over eighty spectators, although only forty-four seats were seated. The architecture of the theater impressed the contemporaries and visitors of the city with its majesty, it was one of the most beautiful buildings of the city, although the theater had significant drawbacks: there was no lobby, winter theater was not heated, lighting was also poor (oil torches). O. Pushkin visited this theater during his exile and left memories of it in the poem "Eugene Onegin": "The theater is full"14. Although operas at the City Theater played only in Italian, the flowers were expensive enough, one can assume that Jews, who always were indifferent to music, visited the theater, especially since the Duke de Richelieu considered the theater not only an entertainment establishment, but also a place where the musical tastes of the population were brought up.

At various times, the Theater of Love provided the stage for the great Russian dramatic actors M. Shchepkin, P. Mochalov, who, since 1827, have often toured the city; the first Ukrainian theater troupe under the direction of G. Kvitka-Osnovyanenko; prominent actors, singers, theater companies of different countries. Odessa saw on the theaters of its theaters S. Bernard and E. Duce, A. Aldridge and the troupe of the Sicilian theater J. Di Grasso, Berlin's New M. Reinhardt Theater and Greek opera. This, of course, influenced not only the improvement of the general level of culture of the representatives of all the peoples of the

\footnotetext{
13 «Messager». от 13 липня 1822 p. 5 с.

14 Пушкин А. С. Евгений Онегин. Роман в стихах. Предисловие, примеч. и пояснит. статья С. Бонди. М.: Государственное издательство Детской литературы Министерства просвещения РСФСР, 1963. 303 с.
} 
city, but also the development of the theatrical art of the various nations living in the city. Beginning of the nineteenth century - Odessa's heyday: the creation of "Porto-Franco" gradually contributes to the fact that Odessa acquires the status of a European city inhabited by people of different nationalities. Due to the tolerance of Jews by de Ribas and Duke de Richelieu in the early nineteenth century. Jews from Austria and Germany, the so-called Brodsky Jews, are beginning to move to Odessa $^{15}$. The number of the Jewish population in Odessa is growing significantly, and in the 1940s. the number of Jews is twelve thousand, that is, $20 \%$ of the total population. According to the Short Jewish Encyclopedia, "Brod Jews" were rich and educated people, and they brought with them the ideas of Haskalah - the Jewish Enlightenment movement. They advocated a combination of Jewish traditionalism and the achievements of European culture, and although their ideas were persecuted by religion, they found favorable conditions for development in Odessa. A significant achievement of this movement was the opening in Odessa of a comprehensive Jewish school ${ }^{16}$, which became the first swallow in the system of Jewish education. Already in the late nineteenth and early twentieth centuries. Odessa ranked first in the Russian Empire in terms of number of Jewish educational institutions. Increasing the material life of the inhabitants of Odessa through the opening of the free economic zone "Porto-Franco" significantly influenced the level of cultural demand. Beginning in 1817, a large number of national amateur troupes have been created in the city, producing performances in various languages, including Hebrew and Yiddish. Unfortunately, there are very few memories and documentary evidence of this page of Jewish theater in the city, they are purely informational. The first theatrical performances were of a religious nature, were devoted to religious holidays, kept folk elements of Purimshpil, national traditions of parody and improvisation, as mentioned in E. Binevich's studies ${ }^{17}$. The middle of the nineteenth century marked by the heyday of the cultural and spiritual life of the Jews of Odessa, which was aided by the loyalty and

${ }^{15}$ Пен С. «Еврейская старина». Вып. 5. Одесса.: «Мигдаль», 2001. 46 с.

${ }^{16}$ Свидетельство об обучении в школе Одессы (русском и идиш). Государственный архив Одесской области. Ф № 5056, опись № 1, дело № 10, лист, № 11 об.

17 Биневич Е.М. Еврейский театр в Одессе. Очерк 1: А. Гольдфаден и его труппа. Загадки еврейского театра. М., Вестник еврейского университета, 1994. № 3 (7). 4 c. 
support of the city authorities: Governor-General M. Vorontsov, Count F. Stroganov, who rescued the abolition of the Jewish settlement before the Russian emperor, the tutor of the Odessa educational district I. Pirogov. At this time, synagogues became centers not only of spiritual life, but also of musical culture, which is connected with the activities of prominent cantors: N. Blumenthal and P. Minkovsky ${ }^{18}$. In the middle of the nineteenth century many national (professional and amateur) theater companies appear in Odessa. Since 1880, Odessa has been regularly visited by mobile theatrical Jewish troupes, which are successful not only in the Jewish population of the city. As you know from the city press, each theater had its own audience, the performances were sold out. The city newspaper Odesnyk Visnyk constantly provides its pages to Jewish writers and publicists B. Bertenson, O. Rabinovich, I. Tarnopolo, M. Finkel. In 1858, the story of the original Jewish press in Odessa begins: the city government allows the publication of the first newspaper in the Hebrew language "Ha-Melits", later appeared literary and journalistic magazines "Dawn", "Zion", "Day" in Yiddish and in Russian, in the origins of which were Jewish figures: M. Morgulis, I. Orshansky, O. Rabinovich, E. Soloveychik.

In the second half of the nineteenth century. among the Jews of Odessa, there is a growing number of "freelancers", most notably doctors and lawyers, and a special world of Jewish intelligentsia is emerging, providing genuine examples of European culture. Statistics of the special commission on the Jewish issue show that at the end of the nineteenth century. the city was home to $35 \%$ of Jews, most of whom were intellectuals, which undoubtedly influenced the development of cultural life, in particular, the theater arts. At the initiative of the Jewish intelligentsia, cultural societies were established in the city, the oldest of which were the Conversation and the Society for the Propagation of Education among Jews in Russia (1863). Such was the cultural and spiritual life of the Jews of Odessa before the first pogroms of 1859, 1871, 1881, provoked by the royal decrees on the forced assimilation of Jews: "On the Prohibition of Wearing Jewish Clothes" (1850), "On the Prohibition of Jews Shaving the Head" (1850), "On the Prohibition of Jewish Weddings on the Streets with Music" (1850), "On the Prohibition for Jews of Some Electoral Positions" (1857). Odessa police and the

${ }^{18}$ Азарх-Грановская А. В. Воспоминания. Совместный изд-кий проект: Иерусалим - Москва, 2001.198 с. 
imperial press sided with the government's campaign: "All the woes of the Russian and Ukrainian peoples are to blame for the Jews." They were even accused of "provoking an outburst of popular anger" through their activities. ${ }^{19}$ The pogroms significantly changed the lives of the Jewish population both in Russia and in Ukraine. The Jews realized that the path to the survival of the nation was not in assimilation with other peoples, but in the growth of self-awareness, the building of a national destiny with their own hands, in the revival of Jewish statehood. Despite the unfavorable political conditions, the spiritual, cultural and economic status of the Jews is gaining a considerable level. With great difficulty, but continued Jewish professional theater companies under the name of "German-foreign societies".

In the early twentieth century $31.41 \%$ of Jews live in Odessa. At present, there are seven synagogues in Odessa, forty-five prayer houses, two city-wide Jewish charities, eighty-nine educational institutions, two hundred religious primary schools, five major Jewish professional aid societies. Odessa has become a prominent center of Jewish writing, developing in three directions: Yiddish, Hebrew and Russian.

Each direction has its theoretical base, supporters, writers, publications. Every Jewish writer considered it an honor to come to Odessa to pay their respects to the "grandfather of Jewish literature" M.M. Sforim (S. Abramovich) who lived in the city from 1881 to 1917.

Among Jewish writers, one way or another with Odessa, it is necessary to name Ben-Ami (M. Rabinovich), Ben Zion (Simha Alter Gutman), Sholom-Aleichem, who came to the city to organize a Jewish theater; the founder of the new Jewish literature in Hebrew, H.N. Bilyk, whose creativity and social activity was a whole epoch in the life of the Jewish intelligentsia of Odessa in the early twentieth century. During this time, prominent Jewish historians live and engage in scientific and educational activities in Odessa: Sh. Dubnov, J. Klausner, and Y. Hessen, who have developed the scientific foundations of the modern history of the Jewish people. The Jewish Literary Society, chaired by the poet Sh. Frug, sought to acquaint Russian and Ukrainian society with the outstanding achievements of Jewish culture. Similar activities were inherent in the "Jewish Faithfulness and Jewishness Propagation Societies in Odessa" and "Jewish Education in Russia".

${ }^{19}$ Котлер И. Очерки по истории евреев Одессы. Редактор И. Котлер. Иерусалим, 1996. 204 с. 
The 1905 Jewish pogroms provoked a mass departure of Jews to America. There is increasing poverty among the remaining. The city authorities do not conceal anti-Semitic treatment of Jews, there are orders for restrictions in professions, when enrolling in educational institutions; about a significant increase in fines and fees. Well-known figures are under investigation and arrest.

The Revolution of 1917 and the Civil War reconciled the Jews to the rest of the city: they all suffered from famine, cold, looting, constant change of government. However, despite the difficult historical and political circumstances, the cultural and spiritual life of the Jews is getting better: in 1918 elections to the Jewish community of the city were held, a large number of periodicals were published, which reproduced all directions of political, public, and creative thought. Odessa becomes the center of book publishing in Hebrew, with two major publishing houses, Moria and Omanut, operating here. The Mizrach Cinematographic Society shoots a series of documentaries and feature films about the lives of Jews, and literary almanacs are published.

After the establishment of Soviet power in Odessa in February 1920, a new page in the lives of Jews begins. At this time, many of them hold senior positions. "It was a special time for the flourishing of the Jewish culture - a time of gaining power with the Jews. Jewish schools, faculties at universities were opened, books, newspapers, magazines were published in large numbers. It was not from the good life of the Rabinovichs with the Zuckermans that they promoted to official ladders and were appointed to significant leadership positions. And not from the great love for the Jews was the manifestation of anti-Semitism reduced.The old Russian intelligentsia and government officials either escaped the "benefits" of the revolution or were destroyed by the Bolsheviks themselves as an "enemy element". That is where we had to ask for help from Jews, among whom were many merchants, scientists and people of "free" professions - musicians, artists, artists. State Jewish groups were quickly created across the country without taking into account demographic, material, creative and other factors”" ${ }^{20}$.

At this time, the cultural life of the Jews was subordinated to the state and party structures of the city (the "eutections"), whose main purpose was "the communist upbringing of the Jewish masses." The fight against

20 «Статут Одеського Державного Театрального Тресту». Державний архив Одесской области. Ф № 5056, опись № 1, дело № 7, лист № 36-40. 
Judaism begins: large synagogues are closed, religious schools, clubs or workshops are opened, religious signs are destroyed. Publishing in Hebrew is curtailing. In spite of this, "eutectics" became centers of Jewish culture development, at the initiative of which several Jewish schools, a Jewish pedagogical technical school, a Yiddish language department at a university, a Jewish craft school were opened.

In order to unite the economic and artistic and ideological work of the theaters in Odessa, the Odessa State Theatrical Trust is established, acting on the basis of the "Charter on State Theaters and their Association", approved by the VTsVK and the RNA of the USSR since 13.08.1930 21 .

Its structure together with the Odessa Jewish State Theater-Studio under the direction of M. Rubinstein (1930-1932) included: Odessa State Theater of the Revolution, Odessa State Russian Drama Theater named after A. Ivanov; Odessa State Theater of Working Youth (TROM), as well as auxiliaries to these theaters of enterprises, institutions and establishments. The Trust had its own "Statute", which defined the range of activities, estimates, governing bodies, time of reporting. The Theater Trust worked in 1931-1933. He reported on his work at the end of the year, as evidenced by relevant archival documents.Their analysis proves that the repertoire of the Jewish theater met the requirements of the time, although the number of performances was less than that at the A. Ivanov Theater and the requirements of the Trust. A total of one hundred and forty-four performances were shown in 1931, one hundred and sixty-eight performances in 1932. Eighty-four thousand people visited the theater in 1932, including fifty thousand workers, twelve thousand servants, eight thousand Red Army men, nine thousand students, five thousand unorganized spectators. This testifies to the great popularity of the theater among the various segments of the population of the then Odessa.

In the two years of its existence, the Odessa Theater Trust has hosted nine touring groups: the State Ukrainian Musical Theater (DUMT); Moscow Small Theater; Blue Blouse Theater; Drama Ballet; Polish Theater; Small Theater Studio; Alexandrina Theater; MOSCOW STATE; Leningrad satire theater.

${ }^{21}$ Уриэль Акоста. O смертности души человеческой [Электронный pecypc]. - Режим доступа к журналу: http // abuss.narod.ru. / Biblio / akosta1.htm. M., 1958. 20 c. 
The 1932 Odessa «Theater Association Memorandum» notes that Jewish theater grew out of the studio and required increased costs. Three hundred and fifteen pieces in the city and the region have been staged in a year. Artistic director of the theater director M. Rubinstein invites six new actors to the theater, sometimes temporarily inviting stage directors from Moscow theaters. At that time, the State Jewish Theater was comprised of ninety-five workers, Chief. thin. part - director M. Rubinstein, assistant director - E. Binus, Head. literary part I. Drucker, artists - Soifer, I. Rabichev, Ugodovsky, Mandelberg, conductors - S. Kaganovich, I. Feintuh, I. Steinberg, twenty-eight actors. The theater's repertoire includes contemporary plays such as "Shot", "In those years", "Around the Tent", "Fifth Horizon", "Julis", and "Zhyzstroy". Despite such activity by the Jewish Theater, the findings of the 1932 commission were rather negative.

In 1935 the Jewish State Theater was organized under the direction E. Leiter, who successfully worked before the Great Patriotic War and was known outside Odessa. In 1941, a Jewish theater was evacuated to Tashkent. He returned to the city at the end of the war, but his premises were already occupied. The theater is located in the city of Balta, and its performances are also held in Odessa. The last performance was the play Freelex (1948), after which the theater ceased to exist.

Thus, it can be said that before the Great Patriotic War the Jewish population of Odessa had a full spiritual and cultural life. Cultural heritage of the Jewish community of the region of the twenties and forties became a treasure trove of world culture. Immediately after the war, thanks to the active work of the Jewish Anti-Fascist Committee, the cultural life of the city's Jews is revived: Jewish theater returns, Yiddish radio broadcasts, and Jewish writers' work continues.

However, as early as 1948, the Stalinist government began the fight against "cosmopolitanism", which resulted in the destruction of almost all manifestations of Jewish culture. Jewish theater closed, all Jewish writers arrested, rabbi, closed and reconstructed last synagogue, remnants of ethnographic museum exposition transferred to different museums, Jewish literature and periodicals removed from libraries and destroyed, and other massacres began.

Subsequently, the cultural and spiritual development of the Jews of the city was greatly reduced. The process of complete assimilation, isolation from national roots has become almost irreversible. The religious community was in control of the government and obeyed its instructions. Subsequently, one synagogue was opened, which was 
mostly visited by the elderly. In the seventies and eighties, there were several "underground" Hebrew and religious canons in Odesa, which led to conspicuous litigation (1971-1985). There were unspoken orders from the authorities about certain restrictions on the admission of Jews to higher education institutions. These facts provoked the emigration of the Jewish population to the United States and to the Palestinian lands created in Israel. Again, the first came the representatives of the Jewish intelligentsia: artists, musicians, writers and more.

This situation continued until the nineties of the twentieth century, when the Soviet Union ended. Together with the great nations that have been striving for independence for many years, they have gained independence, and with it the opportunity to revive and develop all aspects of cultural and spiritual life, small nations, including the Jews of Ukraine.

Today, more than fifty thousand Jews live in Odessa, who have their own schools, kindergartens, university, creative theater groups, musical theater, various clubs and interest groups, are actively engaged in educational, scientific, memorial activities. There are several religious communities in the city that have restored worship buildings that were previously Jewish. They celebrate their holidays, which are broadcast on radio and television broadcasts. All the ideas and creative ideas of the Jewish society, which testify to the state of activity of Jews at the present stage, supports the city authorities. The Odessa Society of Jewish Culture coordinates the activities of local Jewish organizations and foreign missions: the Israeli Information Center, the Sohnut World Agency, the Joint American Jewish Distribution Committee, and the Odesa United Jewish Community, which are worthy of inheritance. Under difficult conditions today, the society solves the problems of the Jewish people, who nevertheless retains their history dating back over two thousand years. In 1999, the Odessa Society of Jewish Culture began its activity, which subsequently became an association of many Jewish organizations.

\section{Some characteristics of the character of the Jews}

The original idea of national character traits can be obtained by reading works of art, theater, created by Jewish writers, directors, and artists from other countries. The first "heroes" of the ritual Jewish theater, besides God, were the characters of the mysteries, the kingsfounders of the Jewish state, and the famous righteous. In the Middle 
Ages, Leche and Badhana, who could be considered the first directors and directors, portrayed compatriots as they were in everyday life, ridiculing ridiculous and negative features, such as fussiness, stupidity, talkativeness.

The attitude of writers and playwrights to the representatives of the Jewish nation during the Renaissance changed somewhat when the philosophical treatise «On the Mortality of the Human Soul» ${ }^{22}$ was authored by Uriel Acosta. In general, the emergence of the stage "hero" a Jew can be said only with the emergence of professional theater and the development of Jewish dramaturgy, when the plays appeared A. Goldfaden, J. Gordin, M. Perets, Sholem Aleichem, A. Asha, A. Schomer, I. Latiner. They portrayed such national traits as a remarkable ability to adapt to environmental conditions, practicalism and rationalism, thriftiness, ingenuity, vigor and, at the same time, cunning, exaggerated religiosity, greed and avarice, while ridiculing their folly and complexity heroes. In the European theatrical tradition, the stage image of a Jew is made in the fifteenth and sixteenth centuries in England $^{23}$. There were two typical images in English theater. The first was borrowed from the play "Three London Ladies" by R. Wilson (1564), written in the genre of morality, whose character Herontos was positive, the other image - from the tragedy "The Jew of Malta" (1588-1592) by the English playwright K. Marlowe a greedy banker who could kill his own daughter for money.T he professional play of the famous actor E. Keen and the music of the Jewish composer A. Nathan caused the negative attitude of the English society to the Jewish nation.

At the request of the English public, Shakespeare continues a series of negative images of Jews in his works.Thus, in the romantic comedy "The Merchant of Venice" (1596) the cruel Jew Shylock becomes a type of comedy thief, negative, ugly and comical. Later in R. Sheridan's plays The School of Affliction and Duenne, the depiction of Jews preserves farcical features of Jewish characters, which became typical of the English scene until the early twentieth century.

In the late medieval German and Austrian plays of the 16th-17th centuries. the Jew acts as a thief and a demonic being. However, later this image softened and the Jew became the main character of farce and

${ }^{22}$ Коротка єврейська енциклопедія. Т. 8. Ієрусалім, 1996 рік. 786-911 с.

${ }^{23}$ Салтыков-Щедрин М. Е. Собрание сочинений в 10 т. // М. Е. СалтыковЩедрин / Под общей ред. С. А. Макашина; Ред. К. И. Тюнькин; Ил. В. А. Сальникова. - М., 1988. - Т.8. - 573 с. 
comedy, which made it possible to emphasize the characteristic plasticity and language of the Jews.

A new theatrical tradition in German dramaturgy begins with the appearance on the stage of E. Lessing's philosophical drama "Nathan the Wise" (1779), where a wealthy Jew is endowed with such traits as love, tolerance, sincerity. Since then, the image of a positive "hero" - a Jew has been affirmed on the German stage.

In the middle of the nineteenth century. There are dramas appearing on the German stage, the main character being a Jewish woman.The first European play to address the problems of women's emancipation from religious dogmas was K. Hebbel's tragedy, "Judith." Subsequently, an image of a Jewish intellectual and humanist (K. Gutskov "Uriel Acosta") appears on the German stage.

French and Italian theatrical traditions until the middle of the XIX century. were no different from English and German in creating the image of a Jew on stage. He was a farce hero, a negative and grotesque character. On the stage, the technique of comparing the images of Jewish men and women is widely used, where men are cartoonish and ugly and women are bright and majestic. Since the 80's of the XIX century in the French theater there are performances about the impossibility of a harmonious existence of representatives of the Jewish and Aryan nations (E. Goncourt "Manet Salomon").There is almost no Jewish theme in Italian theater, and if Jewish characters are portrayed, then only with elements of carnivalism.

End of the nineteenth century in Europe it is marked by an outbreak of anti-Semitism, which is reflected in dramaturgy and theatrical performances (G. Ibsen's The Enemy of the People).

On the Russian stage, the Jew was introduced at the beginning of the eighteenth century. in the school theater interludes as a comic character who was constantly ridiculed. In the 1840s, the role of the vaudeville "Jew" emerged, where Jews appeared to be ridiculous, greedy, and ambitious (the vaudeville "The Jew is Seduced", "The Jew by the Seal", "The Pitmen", by P. Grigoryev. On the professional dramatic scene, the image of a Jew appeared in 1852, when O. Pushkin's "The Knightly Knight" was first staged. From this time, the Russian stage stereotype of a greedy Jew, a man who has neither honor nor conscience, is capable of doing anything for the sake of profit. All national traits of ridicule and even indecent pronunciation and fussy plastic are ridiculed ("Baal" O. Pisemsky, "Tatiana Repina" O. Suvorin). The criminal pragmatism of the Jew is contrasted with the impractical idealistic soul of the Russian 
man ("The God of the Century" by M. Potekhin). The tradition of portraying Jews as a nation of swindlers, ignorants, cowards continued the variety of Jewish actors P. Weinberg, V. Henkin. In the early 1920s, a wave of anti-Semitic sentiment erupted in Russia. In many theaters, the play Smugglers (Sons of Israel) by S. Lytvyn-Efron and V. Krylov was staged, where Jews were portrayed in an obscenely caricature manner that caused a public scandal that prepared the Russian public for the play. E. Chirkov "Jews". The author treats his characters with deep sympathy and sympathy, and regards their fate as a world tragedy.

In Ukrainian dramaturgy, the theme of Judaism is covered in the works of L. Ukrainka (the dramatic poems "Obsessed”, "Johanna, the Woman by Husov"), M. Kulish “One Hundred Thousands”, I. Franko ("Moses”), in which the Jews are endowed with the features of a patriot and of the rightwing man, but this attitude towards the image of a Jew can be considered an exception. The analysis of the literature proves that the writers either portray the representatives of the Jewish people negatively or bypass the Jewish question in silence. Even when they sympathize with certain representatives of the Jewish people (as, for example, in the works of I. Turgenev "The End of Chetrophanov", F. Dostoevsky "The Dead House", A. Chekhov "Step", M. Nekrasov "Contemporaries", V. Korolenko stupid society ", I. Franko" My familiar Jews "," To the Jewish issue ", I. Karpenko-Kary" Sava Chaly ", etc.), all the same - the Jew in their works acts as a comic, caricature, associated with a spy," stingy knight ", prone to venality, pettiness, shrillness, gendering.

M. Nekrasov Jews are greedy, lustful, in the works of A.Chekhov can find such ridiculous Jewish names as "Chepchyk", "Rosalia Yosypovna Aroma", "Jew Perchik", "Madam Gnusik", "Jew Tsypchik". Gogol, describing the Jewish pogrom, emphasizes the ridiculousness of the Jews ("Taras Bulba"), I. Turgenev, sympathizing with the "spy-Jew" writes: "He was really funny, despite all the horror of his condition. The painful anguish of separation from her daughter, the family was expressed by the unhappy Jew with such strange, ugly body movements, screams, jumps, that we all smiled involuntarily, though terrifyingly, it was horrifying to us "(Gid).

In F. Dostoevsky, Isai Fomich is also a funny figure. Everything in it is funny: "the appearance is like a chicken, it has a funny motif, while making prayer it makes funny gestures and puts on funny decorations, so it seemed that some funny horn came out of Isaiah Fomich's forehead" ("Dead House"). M. Saltykov-Shchedrin brings out a whole range of images of Jews - merchants, rich people who speak 
with accent and have funny manners, dress in European, have no paces and speak "almost correctly"("Hard year","Modern idyll"). In addition to the funny talk, he notes the outlandish clothing of the Jews, movements and manners: "the Jew is most reminiscent of the appearance of a teenager who got tangled in his pants Funny lapdard, funny paces; necessary? A Jew does not walk like people, and does not speak like people, and does not look like people"24. V. Grossman describes the Jewish family as: "they are loud-spoken, love-loving, good-natured, hospitable and expressive of superficial optimism"25. D. Zaslavsky, examining the subject of Jewry in literature, concludes: "Jews, for the most part, remained for literature beyond humanity, a semi-savage tribe capable of producing only spies, moneylenders, and merchants. At this time in the west (as early as the early nineteenth century), enlightened society was read by "Nathan the Wise," and the name of the philosopher Mendelssohn was widely known ${ }^{26}$.

The term "theatricality" was coined by M. Jewish, a playwright, theorist, and historian of the performing arts known in the early twentieth century. "Man has an instinct. I mean the instinct of transformation, the instinct of opposing images taken from the outside, images arbitrarily created by man, the instinct of transforming the qualities of Nature. The term "theatricality" means the term aesthetic demonstration of a clearly tendentious character, which, even away from the theater building, with one charming gesture, one beautifully intoned word, creates in our imagination scaffolding, scenery and frees us from the shackles of reality easily, joyfully and all invariably ${ }^{27}$.

One of the critics of the Jewish theater Chaim Flexer (Akim of Volyn) believed that: "Jews are by nature theatrical. All of them - conversation, intonation, gesture, movement, plastic, all figure and posture are expressive and must exist on the stage" ${ }^{28}$. He regarded the gesture of the Jews as a peculiar language - "real, lively, sharp, sharp", and the Hebrew language "a fragment of opera from life", which "turns into a real aria in the synagogue

${ }^{24}$ Гроссман В. На еврейские темы. Избранное в двух томах., Т. 2. Израиль.: Библиотека - Алия, 1990. 532 с.

25 Заславский Д. Евреи в русской литературе. «Еврейская летопись»: Сб. I, 1923. Петроград-Москва.: Изд-во «Радуга». 158 с.

${ }^{26}$ Евреинов Н. Н. Театр как таковой. Под ред. П. Ярославцева, ІІ изд., доп. Одесса: Студия «Негоціант», 2003. 192 с.

27 Волынський А. Еврейский театр. Статья 1. Ипокрит. «Жизнь искусства». Л., 1925. № 27 (901). 2-4 с.

${ }^{28}$ Ibid. 
and is the second nature of the Jew"; he noted that the course of the Jews, both in life and on stage, was "clear and solemn." The clothing of the Jews retains the characteristic features of the whole nation, because the Jews "always remain themselves", the bearers of what they live" ${ }^{29}$. The most valuable in the Jewish actor is his "temperament, his quick excitement and vulnerability, his emotionality, which is often a component of power and hinders the expectation of artistic drawing" 30 . Other researchers also note the emotionality and theatricality of Jews: M. Beregovsky, V. Levitina, M. Loev, J. Roth. In their opinion, "fly", "clown", "clown" - is a characteristic feature of almost every Jew from birth.

Thus, the analysis shows that the world writers of the sixteenth and twentieth centuries rather unilaterally reflected the characteristic features of the Jewish nation. Therefore, describing the national traits of the character and temperament of the Jews, we relied on the research of American psychologists D. Katz and T. Braille, who interviewed students at the last year of Princeton University (in 1951, 1967, 1969). Students were required to select, from many adjectives, the most characteristic features of a nation. Jews are characterized by students as shrewd, prudent, hardworking, resourceful, energetic, flexible thinking, rationalism, able to see perspective, avaricious, able to adapt to living conditions, persistent, intelligent, ambitious, cunning, inclined to family purposeful, aggressive, too religious, with a manifestation of the "offended" complex ${ }^{31}$.

The results of this study are supported by our own observations of representatives of this nation.Communicating with Jews for ten years and observing their behavior, because "character does not exist without appropriate behavior" ${ }^{32}$ lead us to believe that the above character should be attributed to a theatricality, which is possibly the "generic code" ${ }^{33}$ of the Jewish nation developed. in conditions of constant persecution and oppression in a foreign country.

${ }^{29}$ Волынський А. Еврейский театр. Статья 1. Ипокрит. «Жизнь искусства». Л., 1925. № 27 (901). 2-4 c.

30 Ibid.

31 Мацумото Д. Психология и культура. Современные исследования. СПб.: Прайм-Еврознак, 2002. 416 с. (Серия «Психологическая энциклопедия»).

32 Швєцова А. В. Національний характер як феномен культури. Сімферополь: Республіканське видавництво «Таврія», 1999. 265 с.

${ }^{33}$ Корнієнко Н. М. Театр як діагностична модель суспільства. Деякі універсальні механізми самоорганізації художньої культури: автореферат дис. на здобуття наук. ступеня д-ра мистецтвознавства у формі наук. доп.: 17.00.01 / АН України. К., 1993. 77 с. 


\section{CONCLUSIONS}

Thus, the analysis of the existing archival documents, scientific and memoir literature, periodicals, and the memoirs of contemporaries allow us to believe that the cultural and spiritual life of the Jews of southern Ukraine, in particular Odessa, is one of the brighter page among the cultural heritage of all peoples living long ago on this territory. And, it can be noted that the emergence of Jewish national theatrical art was due to both objective and subjective factors. Objective factors include the genetic preservation of the ritual ritual theater that was developed by ancient Jews long before the advent of ancient theater, as evidenced by historical and literary sources. Among the subjective factors that led to the emergence of theater, prominent actors known worldwide are the peculiarities of the temperament and character of the Jewish nation, their theatricality, emotionality, excitability.

\section{SUMMARY}

We consider it appropriate to consider the cultural and spiritual life of the Jews of Odessa, which is directly related to the formation and development of Jewish theater art. The antiquity and strength of ties between the Ukrainian and Jewish peoples date back to the times of Kievan Rus. It can be stated that throughout the history of Judaism in Ukraine, in cultural, scientific and spiritual life, there was mutual influence and interpenetration.

\section{REFERENCES}

1. Найдорф М. И. Введение в теорию культуры: Основные понятия культурологи. Одесса: Друк, 2005. 192 с.

2. Курас I. Ф. Євреї в незалежній Україні: проблеми наукових досліджень. «Політика і час». № 8. 1994. 41-51 с.

3. Овчаренко Т. С. Національний імідж як елемент театральної культури. Аркадія: культурологічний та мистецтвознавчий журнал. Одеса, 2004. № 2(4). 48-50 с..

4. Сухарев В. А., Сухарев М. В. Психология народов и наций. Донецк: Сталкер, 1997. 400 с. .

5. Рот С. Искусство в еврейской традиции. Иерусалим: Б-ка Алия, 1989. № 852. 208 с.

6. Евреинов Н. Н. Азазел и Дионис. О происхождении сцены в связи с зачатками драмы у семитов. Л.: "ACADEMIA", 1924. 203 с.

7. Малышевский И. Евреи в Южной Руси и Киеве в X-XII веках. Киев, 1878.116 с. 
8. Маринович М.Ф. «Про міжконфесійну ситуацію в Україні». Релігійне життя. Права людини в Україні: К.-Х.,1993. С. 50-56.

9. Історія релігії в Україні: навч. посібник/ НАН України. І-нт філософії, Відділ релігієзнавства; За ред.. А.М. Колодного, П.Л. Яроцького. К.: Знання, 1999. 735 с.

10. Фентон Джон. Древнейшая жизнь евреев. Социологический етюд (перевод с англ.). М.: Типография А. И. Мамонтова и Комп., 1884. № 5.354 c.

11. Котлер И. Очерки по истории евреев Одессы. Редактор И. Котлер. Иерусалим, 1996. 204 с.

12. Голота В. В. Театральная Одесса. К.: Мыстэцтво, 1990. 245 с.

13. «Messager». от 13 липня 1822 p. 5 с.

14. Пушкин А. С. Евгений Онегин. Роман в стихах. Предисловие, примеч. и пояснит. статья С. Бонди. М.: Государственное издательство Детской литературы Министерства просвещения РСФСР, 1963. 303 с.

15. Пен С. «Еврейская старина». Вып. 5. Одесса.: «Мигдаль», $2001.46 \mathrm{c}$.

16. Свидетельство об обучении в школе Одессы (русском и идиш). Государственный архив Одесской области. Ф № 5056, опись № 1, дело № 10, лист, № 11 об.

17. Биневич Е.М. Еврейский театр в Одессе. Очерк 1: А. Гольдфаден и его труппа. Загадки еврейского театра. М., Вестник еврейского университета, 1994. № 3 (7). 4 с.

18.Котлер И. Очерки по истории евреев Одессы. Редактор И. Котлер. Иерусалим, 1996. 204 с.

19. Азарх-Грановская А. В. Воспоминания. Совместный издательский проект Иерусалим - Москва, 2001. 198 с.

20. «Статут Одеського Державного Театрального Тресту». Державний архив Одесской области. Ф № 5056, опись № 1, дело № 7, лист № 36-40.

21. Уриэль Акоста. О смертности души человеческой [Электронный ресурс] - Режим доступа к журналу: http //abuss.narod.ru./ Bibli/akosta1.htm. M., 1958. 20 c.

22. Коротка єврейська енциклопедія. Т. 8. Ієрусалім, 1996 рік. 786-911 c.

23. Салтыков-Щедрин М. Е. Собрание сочинений в 10 т. // М. Е. Салтыков-Щедрин / Под общей ред. С. А. Макашина; Ред. К. И. Тюнькин; Ил. В. А. Сальникова. - М., 1988. - Т.8. - 573 с. 
24. Гроссман В. На еврейские темы. Избранное в двух томах., Т. 2. Израиль.: Библиотека - Алия, 1990. 532 с.

25.Заславский Д. Евреи в русской литературе. «Еврейская летопись»: Сб. I, 1923. Петроград-Москва.: Изд-во «Радуга». 158 с.

26. Евреинов Н. Н. Театр как таковой. Под ред. П. Ярославцева, II изд., доп. Одесса: Студия «Негоціант», 2003. 192 с.

27. Волынський А. Еврейский театр. Статья 1. Ипокрит. «Жизнь искусства». Л., 1925. № 27 (901). 2-4 с.

28. Мацумото Д. Психология и культура. Современные исследования. СПб.: Прайм-Еврознак, 2002. 416 с. (Серия «Психологическая энциклопедия»).

29.Швєцова А. В. Національний характер як феномен культури. Сімферополь: Республіканське видавництво «Таврія», 1999. 265 с.

30. Корнієнко Н. М. Театр як діагностична модель суспільства. Деякі універсальні механізми самоорганізації художньої культури: автореферат дис. на здобуття наук. ступеня д-ра мистецтвознавства у формі наук. доп.: 17.00.01 / АН України. К., 1993. 77 с.

\section{Information about the author:} Ovcharenko T. S.,

Candidate of Cultural Studies, Associate Professor of the Department of Cultural Studies, art and philosophy of culture Odessa National Polytechnic University 1, Shevchenko av., Odesa, 65044, Ukraine 